\title{
HET VRAAGSTUK VAN HET BEHOUD VAN HET WATER OP CURAÇAO
}

DOOR

\section{J. Beijering (Curaçao)}

Het is welhaast aan ieder die de Nederlandse Antillen heeft bezocht bekend, dat een van de grootste moeilijkheden waarmede onze Benedenwindse Eilanden te kampen hebben, het watervraagstuk is. Vóór de vestiging van de grote industriën kon er weliswaar van een tekort aan drinkwater nauwelijks gesproken worden - immers, wanneer de regenbakken dreigden leeg te raken had men drinkbaar putwater genoeg, al kwam men met de aanvoer wel eens in moeilijkheden - de landbouw en de tuinbouw hadden bijna voortdurend met een tekort aan water te kampen. Op initiatief van de toenmalige Gouverneur van Curaçao, Jhr. J. O. DE Jongh van BeEk EN Donk werd dan ook omstreeks 1908 begonnen met systematische damaanleg op Curaçao onder leiding van ir. M. C. FAUEL, destijds Directeur van Openbare Werken, die zich blijkbaar ook bijzonder voor deze aangelegenheid interesseerde. Dat het deze heren ernst was, blijkt wel uit een aan de toenmalige Minister van Koloniën uitgebracht rapport, waarin een bedrag van $f$ 1.000.000.- (voor die tijd een respectabele som) werd gevraagd om deze zaak met kracht ter hand te kunnen nemen. Op deze credietaanvrage werd echter afwijzend beschikt, waardoor de werkzaamheden van beperkte omvang bleven en tenslotte geheel werden stilgelegd. Het doel dat men hierbij voor ogen had, was, zodanige werken aan te leggen dat het in de regenperiode (Oct. t/m Jan.) in grote hoeveelheden bovengronds naar zee afstromend regenwater werd opgevangen in damreservoirs, om daar ter plaatse in de bodem te dringen. Dus waterconservatie in de letterlijke zin des woords.

Door de vestiging van de olie-industriën en de daarmee gepaard gaande grote bevolkingsaanwas als gevolg van een zich snel ontwikkelende hoogconjunctuur (het inwonertal van het

$$
-65-
$$


eiland Curaçao b.v. steeg van 33.000 in 1910 tot 92.000 in 1948) wordt de grondwaterreserve in steeds stijgende mate aangesproken en wordt de noodzaak, zo mogelijk deze grondwaterreserve op peil te houden of zelfs te verhogen, eveneens dringender. Het grondwatertekort doet zich wel in de eerste plaats gevoelen ten behoeve van de industrie en de drinkwatervoorziening. Wat de drinkwatervoorziening betreft tracht men het probleem op te lossen door het in bedrijf stellen van steeds meer zeewaterdestillatie inrichtingen om het tekort aan putwater te dekken, doch het destilleren van zeewater blijft nog altijd een dure geschiedenis, zodat uit economische overwegingen het streven er dan ook steeds op gericht zal moeten zijn zoveel mogelijk grondwater en zo weinig mogelijk gedestilleerd water te gebruiken. Naast de grondwaterreserve ten behoeve van huishoudelijk gebruik staat het grondwaterverbruik voor landbouwdoeleinden (w.o. irrigatiewater) en nu schijnt het uiteraard alsof de belangen van deze twee groepen lijnrecht met elkaar in strijd zijn. Tot op zekere hoogte is dit natuurlijk ook waar, doch indien het oppompen van water voor huishoudelijke doeleinden niet al te geconcentreerd geschiedt, d.w.z. als de pompinstallaties over een grote oppervlakte verspreid zouden worden, dan zal het grondwaterpeil in algemene zin daar slechts weinig invloed van ondervinden. Desniettemin blijft het ten allen tijde geboden al 't mogelijke te doen om de grondwaterreserve zo hoog mogelijk op te voeren omdat de grondwatervoorraad mede een der hoofdvoorwaarden is om aan land- en tuinbouw ontwikkelings- en bestaansmogelijkheden te bieden.

Middelen die tot verhoging van het grondwaterpeil kunnen leiden.

Teneinde een verhoging van het grondwaterpeil te kunnen bewerkstelligen zou men twee wegen kunnen inslaan nl.:

le. Trachten de ondergrondse afstroming naar zee te verhinderen.

2e. Zodanige maatregelen nemen dat een grotere hoeveelheid van het neerslagwater in grondwater overgaat.

ad Ie. In het bekende plan-Molengraaff, dat werd uitgebracht in 1921 in verband met de Watervoorziening van Stad en Haven van Curaçao, worden enkele methoden besproken die dit doel beoogden. In de eerste plaats wordt in dit plan aan een beschouwing onderworpen de door Mörzer BRUINS en ir. GRAADT VAN ROGGEN aanbevolen methode om de zich onder een 
bovengronds damlichaam bevindende waterdoorlatende laag door inspuitingen met cement ondoorlatend te maken - eventueel voortgezet tot op de heuvelhellingen aan weerszijden van de dam - en dan het zich voor deze afsluiting opstuwende grondwater door putten ter beschikking te krijgen.

Een soortgelijke methode werd ontworpen door ir. VAN LIDT DE Jeude en ir. Duyfjes die de cement-inspuitingen - voornamelijk omdat men daarbij niet kan zien wat men doet vervangen door respectievelijk een beton- en een kleikist, welke dan plaatselijk wel tot ongeveer dertig meter diepte zou moeten worden gestort.

Als zijnde te kostbaar en in de practijk buitengewoon moeilijk uitvoerbaar, werden deze denkbeelden in het plan-Molengraaff zeer stellig verworpen.

In Economische Voorlichting, d.d. 7 Sept. 1949, wordt in een artikel onder de titel ,Waterdicht maken van de bodem" de aandacht gevestigd op een in de laatste vijftien jaren ontwikkelde werkwijze ${ }^{1}$ ) waarbij een zeer fijn verdeelde asfaltemulsie in de doorlaatbare grondlaag gebracht wordt door middel van injectiepijpen. Aan de emulsie is een stof toegevoegd waardoor na een bepaalde tijd de asfaltdeeltjes gaan samenvlokken tot steeds grotere deeltjes en aldus de grondporiën gaan verstoppen.

Of een dezer methoden voor het alhier beoogde doel gebruikt zouden kunnen worden lijkt mij twijfelachtig, en wel hoofdzakelijk om de volgende redenen:

1. Ook in het onverweerde diabaasgesteente, waaruit de vulkanische kern van Curaçao bestaat, kunnen grote spleten voorkomen zodat geen scheiding is te trekken tussen waterdoorlatende en niet-waterdoorlatende bodemlagen. Door waarnemingen van recente datum is komen vast te staan dat zelfs tot op grote diepte deze spleten voorkomen.

2. De aan dergelijke methoden verbonden kosten zijn nog altijd van die aard dat toepassing in het groot economisch onverantwoord geacht moet worden. Voor individuele gevallen ligt de zaak echter anders; zo is b.v. de asfaltemulsiemethode toegepast bij de aanleg van de Nijlstuwdam bij Assioet.

ad 2e. De vraag of het mogelijk is een grotere hoeveelheid van het neerslagwater in grondwater te doen overgaan kan zonder enige twijfel bevestigend worden beantwoord. Deze mogelijk-

1) Het z.g. Shell-Perm procédé; zie ook Kon. Shell Nieuws 2, Juni 1949, no. 6 en Curaçao II, 22 Oct. 1949, no. $2 I$. 
heid is gelegen in het feit dat tot nu toe bij zware regenval grote hoeveelheden water bovengronds direct naar zee afstromen en indien dus zodanige maatregelen genomen worden dat dit niet meer of althans in aanmerkelijk mindere mate geschiedt, zal het gestelde doel bereikt kunnen worden.

Een bedamming s plan.

Het hierboven gestelde en bereikbaar geachte doel zal het beste kunnen worden verwezenlijkt door de aanleg van een zo doeltreffend mogelijk bedammingssysteem. Teneinde een indruk te geven wat met een bedammingssysteem bedoeld wordt, is hiernaast een schetskaartje afgebeeld (fig. 1).

Bij zware regenval verzamelt het water zich in de laagten tussen de heuvels, vanwaar het door beddingen, de zogenaamde rooien, met grote snelheid naar zee stroomt. Een rooistelsel is te vergelijken met een rivier met talrijke zijtakken, met dit verschil, dat deze rooien slechts water afvoeren in perioden van zware regenval. In deze rooien nu worden op punten, welke in hoofdzaak bepaald worden door de topografische gesteldheid van het terrein, dammen gebouwd van dusdanige afmetingen dat het reservoir van een bepaalde dam groot genoeg van inhoud is om de te verwachten waterhoeveelheid op dat punt te kunnen bergen.

De grondgedachte wat betreft het middel dat tot het gewenste doel kan voeren is dus sinds 1910 (FAUEL) eigenlijk niet veranderd. Het is echter wel gebleken dat de dammen van het systeem FAUEL geen volledige oplossing zijn, aangezien de reservoirs dezer dammen veel te klein van inhoud waren. Bij een volgens dit systeem ,,volledig” bedamd gebied werd zeker niet meer dan 20 à $25 \%$ van het afstromende water vastgehouden, doch niettemin zijn de resultaten van de destijds aangelegde werken (aanwezigheid van hofjes met vruchtbomen en i.h.a. een zwaardere begroeiïng) heden ten dage nog duidelijk zichtbaar.

Door de tegenwoordige hulpmiddelen - bij grondwerken grote tractoren met scrapers, bulldozers e.d. - zijn we momenteel in staat dammen te construeren van vrijwel elke gewenste afmeting, zodat de practische uitvoerbaarheid van een bedammingssysteem waarbij uiteindelijk de totale inhoud van alle damreservoirs ongeveer gelijk dient te zijn aan de in een goed regenjaar tot afstroming komende hoeveelheid water, mogelijk geacht mag worden. Als wij nog even fig. 1 beschouwen dan moet dus b.v. het reservoir van de voor het vanggebied $a$ ontworpen 


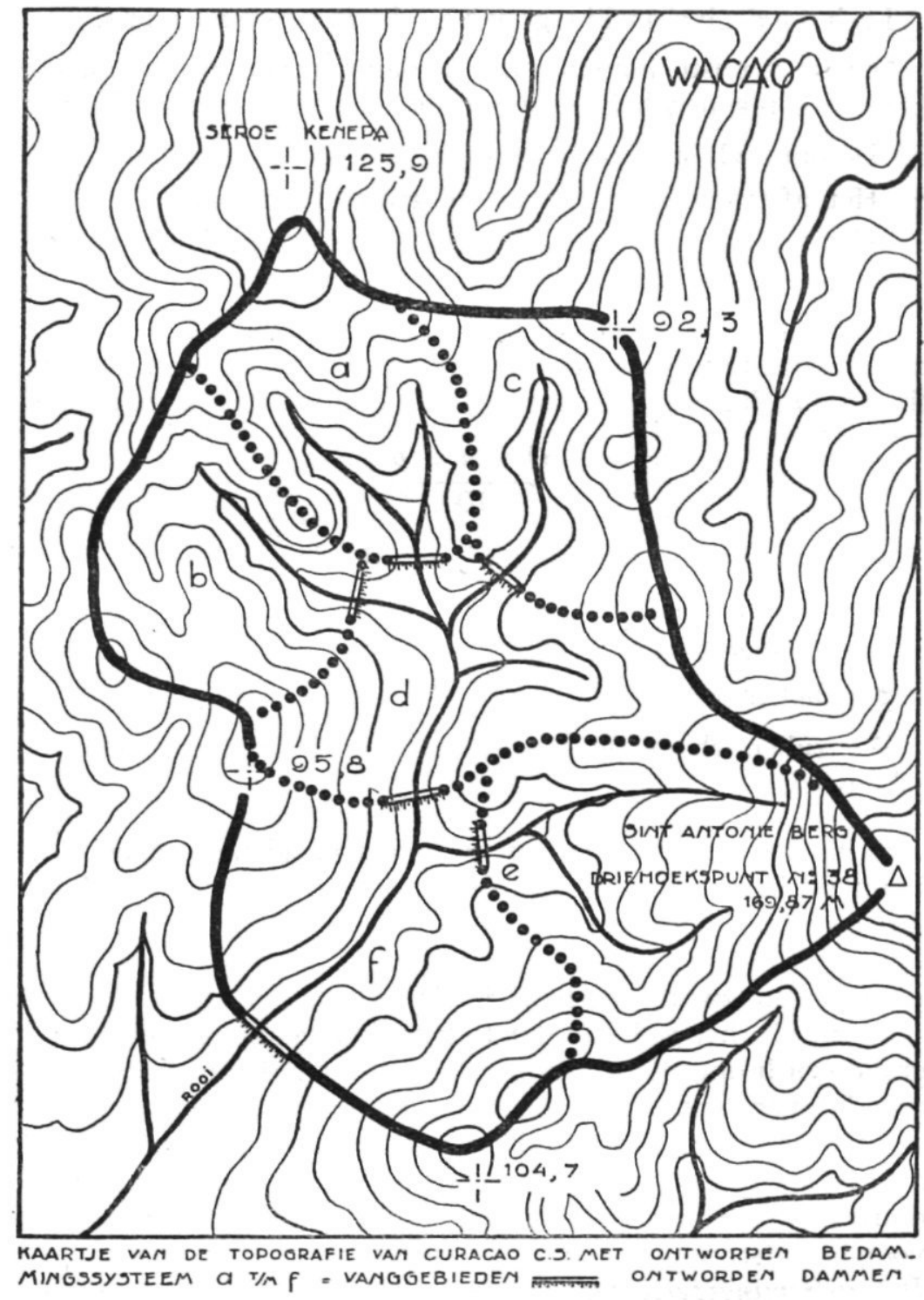

Fig. 1. Schetskaartje van een bedammingssysteem in NoordwestCuraçao. Nadere uitleg in de tekst.

dam een zodanige inhoud krijgen dat daarin de verwachte waterhoeveelheid geborgen kan worden. Hetzelfde is het geval met de dammen voor de vanggebieden $b \mathrm{t} / \mathrm{m} f$. 
Inhoudsbepaling van damreservoirs.

Om de vereiste inhoud van elk damreservoir afzonderlijk te kunnen berekenen hebben we te maken met 3 factoren t.w.:

a. De oppervlakte van het vanggebied boven elke dam.

$b$. Het afstromingspercentage bij zware regenval.

c. Het totaal aantal mm regenval dat als grondslag voor berekening in aanmerking gebracht mag worden.

Noemen we de oppervlakte van het vanggebied $O$, het afstromingspercentage $p$ en de in aanmerking te brengen regenval (hoogte) $h$, dan zou de formule voor de inhoudsberekening luiden

$$
\frac{O \times h \times p}{100}
$$

Als $I$ direct in $\mathrm{m}^{3} \mathrm{zal}$ worden uitgedrukt dan is dus

$O=$ de oppervlakte in $\mathrm{m}^{2}$

$h=$ de regenhoogte in $\mathrm{m}$

$p=$ het procentgetal.

We zullen thans de bovengenoemde 3 factoren nader beschouwen.

ad a. De oppervlakte van de onderscheidene vanggebieden is uit de kaart gemakkelijk planimetrisch te bepalen en levert dus geen moeilijkheden op.

$a d b$. Bij zware regenval is de neerslag in twee delen te splitsen, nl.: het gedeelte dat tijdens de regenbui direct door de grond wordt opgenomen (infiltratie) en een ander deel dat bovengronds afstroomt en via de rooien naar zee verdwijnt. Hieruit volgt dat, zolang de regenintensiteit (regenval per minuut) de infiltratie-capaciteit van de grond (indringingssnelheid per minuut) niet overtreft, geen afstroming zal optreden en als definitie voor het afstromingspercentage zouden we dus kunnen zeggen: Het afstromingspercentage is onder alle omstandigheden gelijk aan het positieve verschil tussen de regenintensiteit en de infiltratiecapaciteit van de grond.

Omtrent het afstromingspercentage waren tot nu toe geen op waarnemingen berustende gegevens ter beschikking en op initiatief van ir. W. C. VISSER (destijds lid van de bekende commissie prof. KruL, welke commissie het meest recent het waterprobleem bestudeerde) 
werd enige tijd geleden met een onderzoek in die richting begonnen 1). Dit onderzoek is er in de eerste plaats op gericht, om inzicht te verkrijgen in het meer of minder grote vermogen van de verschillende grondtypen om water op te nemen (bepaling van de infiltratie-capaciteit). In het algemeen neemt de infiltratie-capaciteit af naarmate de regenval van grotere intensiteit is en langer duurt, tengevolge van dichtslaan van de oppervlakte en verzadigd raken van de bovenlaag. Er werd nu een installatie geconstrueerd waarmee de invloeden van de twee factoren regenintensiteit en infiltratie-capaciteit gescheiden beoordeeld kunnen worden. Het toestel bestaat uit een op een auto geplaatst reservoir van bekende inhoud $(200 \mathrm{l})$ van waaruit water wordt gelaten in een buizenstelsel met gaatjes. Dit buizenstelsel wordt geplaatst in een bak van 1 bij $2 \mathrm{~m}$, ongeveer $40 \mathrm{~cm}$ boven de grond. De bak wordt met zijn langste zijde geplaatst evenwijdig met de helling van het terrein en ongeveer $10 \mathrm{~cm}$ in de grond ingegraven; hij is aan het benedeneind aan de onderzijde van de wand gedeeltelijk opengelaten, waardoor het overtollige water wegvloeit. Het afstromende water wordt opgevangen en gemeten. Een voorbeeld van een proefneming moge duidelijk maken wat op deze manier bereikt kan worden.

Grondsoort: ongeveer $16 \mathrm{~cm}$ fijnkorrelige, enigszins slibhoudende grond, overgaande in tamelijk verweerd, grofkorrelig diabaas.

IJle grasbegroeiïng met lage struiken.

Helling: $3 \%$.

Behandelde oppervlakte: $2 \mathrm{~m}^{2}$.

Hoeveelheid toegediend water: 2001.

Duur van de meting: $61 \mathrm{~min}$.

Berekende regenintensiteit: $1.64 \mathrm{~mm} / \mathrm{min}$.

Aanvang meting: 9.20 uur.

Afstroming begonnen op: 9.23 uur.

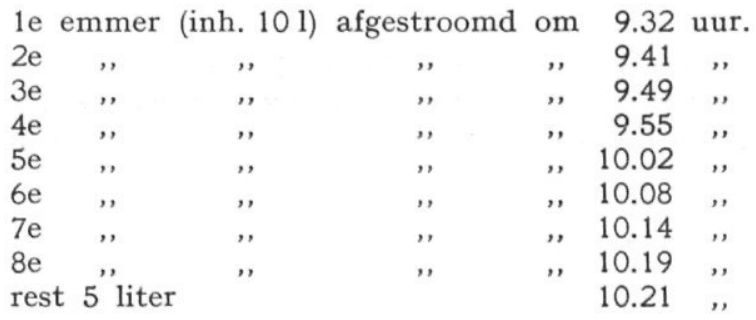

Einde meting 10.21 uur.

Totaal afgestroomd: $8 \times 10+5=85$ liter.

Gemiddels afstromingspercentage: $42.5 \%$.

1) Zie het verslag in VISSER's Nota over de landbouw (p. 33-36), Bijlage 3 van W. F. J. M. KRUL's Rapport inzake de waterhuishouding van Curaçao en Aruba, 1949. Men zie ook het artikel van J. Beijering over ,Waterconservatie en erosiebestrijding op de Nederlandse Antillen", in het Landbouwk. Tijdschr. 6r, Apr. 1949, p. 209-214. 
De met bovenstaande meting verkregen resultaten zijn grafisch voorgesteld in fig. 2 . De geleidelijke afname van de infiltratie-capaciteit en de stijging van het afstromingspercentage (vgl. definitie van het afstromingspercentage) wordt hier duidelijk gedemonstreerd.

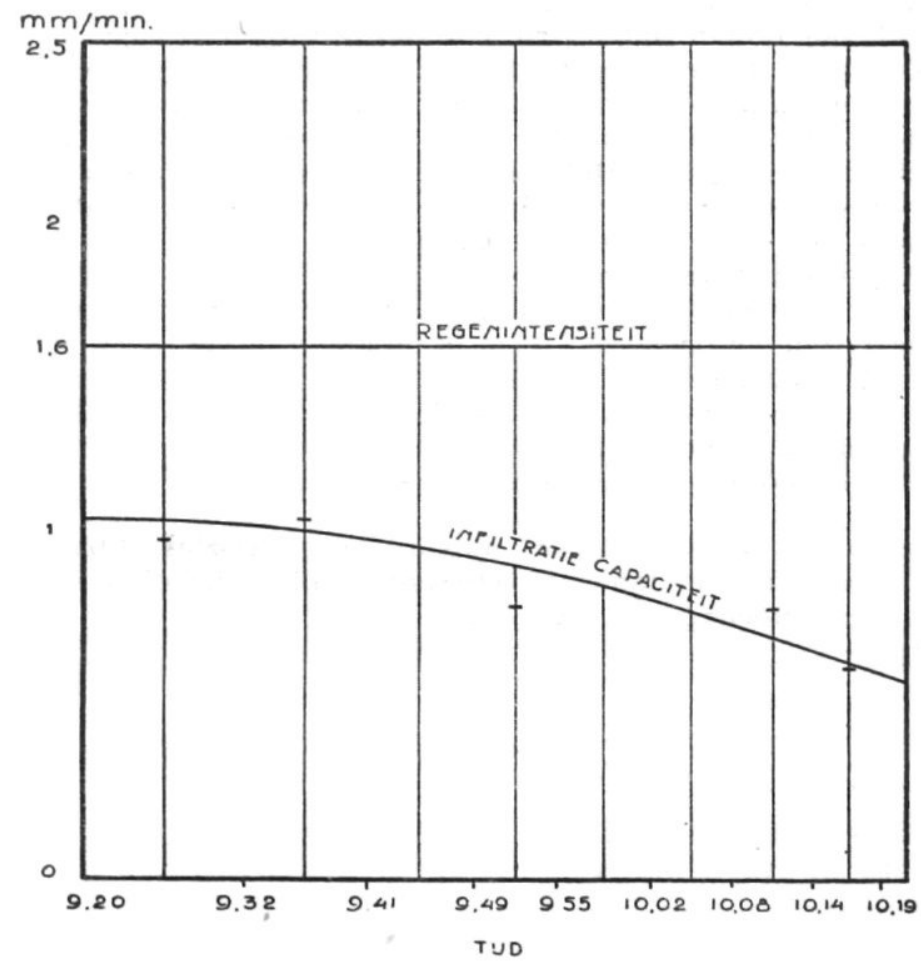

Fig. 2. Grafische voorstelling van de resultaten van de in de tekst beschreven meting van het afstromingspercentage van een verweerde diabaas-grond op Curaçao. De geleidelijke afname van de infiltratiecapaciteit bij aanhoudende regen en de stijging van het afstroompercentage wordt hierin duidelijk gedemonstreerd.

Het zwakke element bij de bovenomschreven proefnemingen is gelegen in het feit dat de veroorzaakte regenintensiteit tijdens de proef constant blijft en waarschijnlijk aan de hoge kant is. In werkelijkheid zal de regenintensiteit tijdens een bui steeds variëren. Ook kan een lagere intensiteit dan $1.6 \mathrm{~mm} / \mathrm{min}$. met het geconstrueerde toestel niet bereikt worden. Aangezien het echter van groot belang is het probleem tot een volledige oplossing te brengen - ook in de U.S.A. en Australië is men t.a.v. dit punt druk in de weer - worden thans intensief pogingen gedaan een zo groot mogelijke technische volmaaktheid van de proeven te bereiken. Het idee is thans, om, evenals de bij de „Soil Conservation Service of New South Wales". gevolgde methode, op proefvlakken van $331 / 3 \mathrm{~m}$ bij $3 \mathrm{~m}$ (0.01 ha), zelfregistrerende regen- 
meters te plaatsen en het afstromende water op te vangen en te meten. Voor dit doel werden reeds een drietal zelfregistrerende regenmeters besteld, welke binnenkort geleverd zullen worden. Een op deze manier opgezet onderzoek voert reeds een stap nader tot het beoogde doel, doch het experimentele onderzoek zal m.i. pas technisch volmaakt zijn indien naast het registreren van de regenval ook de afstroming automatisch zou worden geregistreerd en dan zoveel mogelijk per corresponderende tijdseenheid 1 ). Ter verduidelijking van een en ander moge nog het volgende dienen. Zie als theoretisch voorbeeld fig. 3.

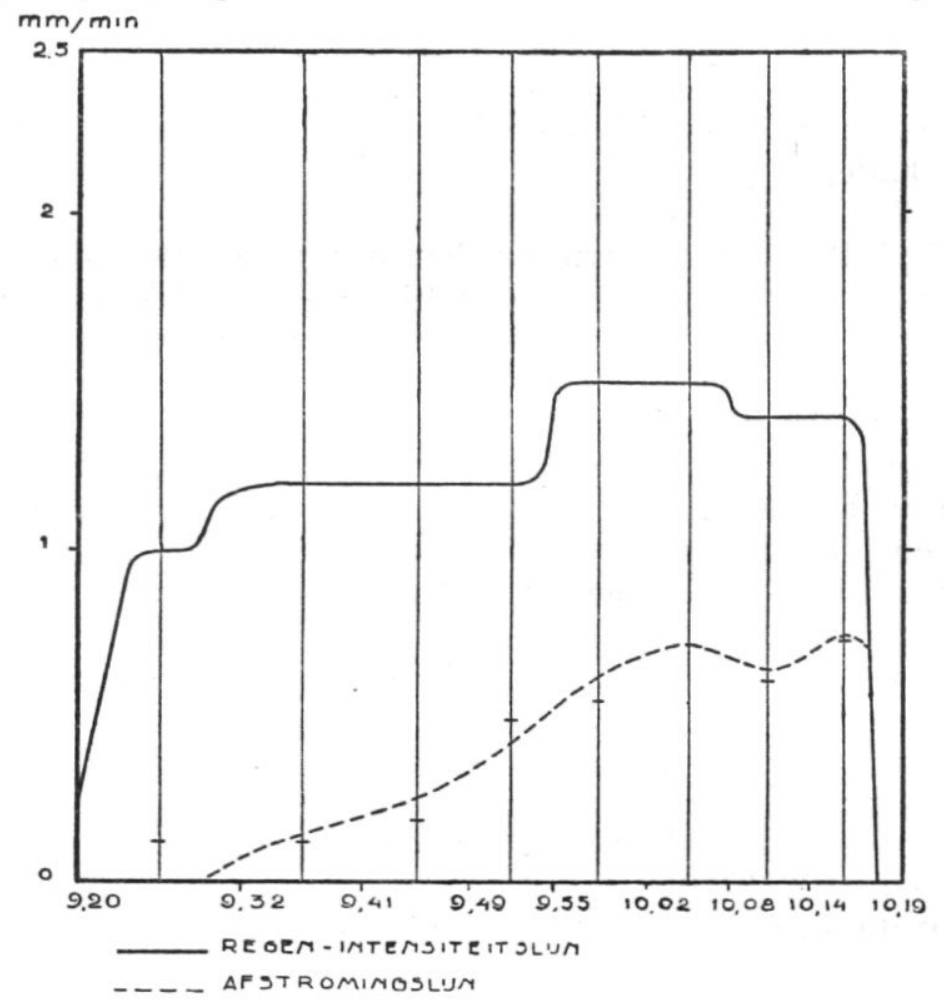

Fig. 3. Theoretisch voorbeeld, hoe de infiltratiecapaciteit (die hier is gelijkgesteld met die in fig. 2) kan worden gemeten na een registratie van de regenval en de afstroming. Verdere verklaring in de tekst.

Uit het diagram dat door de regenmeter wordt geregistreerd kan de regenintensiteit per tijdseenheid (minuut) worden berekend en aldus een regenintensiteitslijn worden geconstrueerd. Blijkt het nu mogelijk ook de afstroming op gelijke wijze te registreren dan zal uit dit diagram

1) Een apparaat dat voor dit doel dienst zou kunnen doen is de schrijver niet bekend. Mochten er onder de lezers derhalve zijn die een apparaat kennen dat voor dit doel dienst zou kunnen doen dan zal een mededeling daaromtrent op prijs gesteld worden. 
een potentiële afstromingslijn zijn te construeren. Het verticale verschil tussen deze twee lijnen zal een inzicht geven in het verloop van de infiltratie-capaciteit van de grond en het verticale verschil tussen de horizontale (nul-lijn) en de geconstrueerde afstromingslijn geeft de afstroming aan. In de tekening is hierbij aangenomen dat de infiltratiecapaciteit verloopt zoals in fig. 2 werd weergegeven (van $1.08 \mathrm{~mm}$ tot $0.64 \mathrm{~mm}$ per minuut).

Tot nu toe wordt veelal aangenomen dat het afstromingspercentage ongeveer uiteenloopt van $20-35 \%$, welke norm evenwel elke grondslag mist. Slechts degelijk opgezette proefnemingen zullen in deze belangrijke kwestie een gefundeerd inzicht kunnen verschaffen.

ad c. Bij dit onderwerp gaat het over de beantwoording van de vraag welke regenval als grondslag voor berekening in aanmerking gebracht mag worden. Deze is hierom zo belangrijk omdat getracht moet worden de meest economische inhoud van de damreservoirs te bepalen. Immers van het kapitaal, besteed aan een dammensysteem waarbij te hoge normen als grondslag gediend hebben, kan een gedeelte als vrijwel weggegooid beschouwd worden, omdat de reservoirs van een dergelijk systeem nooit of slechts hoogst zelden voor $100 \%$ benut zouden worden.

$\mathrm{Nu}$ werd aanvankelijk zó geredeneerd, dat waarschijnlijk het beste als waarde voor de factor $h$ de gemiddelde regenval in de grote regenperiode genomen kon worden. Het hieronder afgedrukte staatje geeft een overzicht van de regenval op Curaçao (gemiddelden van alle waarnemingsstations op dit eiland) over de jaren 1930-1946.

Uit dit staatje blijkt dat de gemiddelde regenval in de grote regenperiode (Oct. t/m Jan.) $413.4 \mathrm{~mm}$ heeft bedragen. De regenval in de overige maanden kan gevoeglijk buiten beschouwing blijven, want al komt het sporadisch voor dat in b.v. April of Mei nog een zware bui valt (1944) dan behoeft hiermede nog geen rekening gehouden te worden omdat tegen October, dus het begin van de grote regenperiode, dit water reeds in de bodem gedrongen zal zijn en de damreservoirs weer hun volle capaciteit bereikt zullen hebben om de stoot van de grote regentijd op te vangen. Bij nadere nauwkeurige bestudering van het onderhavige probleem blijkt echter het denkbeeld van de gemiddelde regenval in de grote regenperiode als waarde voor de factor $h$ niet geheel juist, omdat deze hoeveelheid voor een deel bereikt is door ook 
GEM. REGENVAL OP CURAÇAO OVER 1930-1946

\begin{tabular}{l|r|r|r|r|r|r|r|r|r|r|r|r|r|r|r|r}
\hline & Jan. & Feb. & Mrt. & Apr. & Mei & Juni & Juli & Aug. & Sept. & Oct. & Nov. & Dec. & Totaal \\
\hline 1930 & 37.3 & 3.5 & 1.3 & 0.7 & 1.0 & 21.7 & 5.3 & 3.8 & 3.1 & 28.0 & 39.7 & 84.0 & 299.4 \\
1931 & 23.6 & 20.2 & 0.0 & 6.0 & 8.1 & 5.3 & 49.7 & 64.6 & 21.6 & 9.9 & 164.4 & 166.2 & 539.6 \\
1932 & 120.6 & 13.3 & 6.6 & 9.4 & 53.2 & 30.0 & 29.4 & 28.9 & 17.8 & 237.7 & 300.5 & 153.3 & 1000.7 \\
1933 & 123.5 & 42.6 & 10.7 & 16.4 & 4.7 & 80.1 & 30.6 & 35.4 & 191.6 & 162.0 & 249.2 & 170.8 & 1117.6 \\
1934 & 135.5 & 9.6 & 5.9 & 1.9 & 0.9 & 3.3 & 9.6 & 16.1 & 16.0 & 22.9 & 170.7 & 48.0 & 440.4 \\
1935 & 25.3 & 22.5 & 35.5 & 2.8 & 15.5 & 5.5 & 17.2 & 62.6 & 21.7 & 142.3 & 121.2 & 109.5 & 581.6 \\
1936 & 15.0 & 25.0 & 0.5 & 8.8 & 3.9 & 19.6 & 80.7 & 1.9 & 13.4 & 127.2 & 115.2 & 60.5 & 471.7 \\
1937 & 76.8 & 6.4 & 5.9 & 2.5 & 7.9 & 11.5 & 14.2 & 3.0 & 60.0 & 67.1 & 100.4 & 266.0 & 621.7 \\
1938 & 75.5 & 36.5 & 39.2 & 36.7 & 38.5 & 7.8 & 25.5 & 74.1 & 51.9 & 136.7 & 266.6 & 152.4 & 941.4 \\
1939 & 30.7 & 34.5 & 20.3 & 1.1 & 1.9 & 21.7 & 1.9 & 2.4 & 4.5 & 143.1 & 41.6 & 23.9 & 327.6 \\
1940 & 4.2 & 4.0 & 8.5 & 1.0 & 4.0 & 0.6 & 21.9 & 25.4 & 19.2 & 30.0 & 210.7 & 26.3 & 255.8 \\
1941 & 13.7 & 0.0 & 2.4 & 45.5 & 6.5 & 2.2 & 8.2 & 11.0 & 17.9 & 35.5 & 102.8 & 7.7 & 253.4 \\
1942 & 13.9 & 5.6 & 0.4 & 62.7 & 4.3 & 2.8 & 14.2 & 12.9 & 29.1 & 95.7 & 190.8 & 263.6 & 696.0 \\
1943 & 51.3 & 21.4 & 22.9 & 24.4 & 14.1 & 9.8 & 13.6 & 34.8 & 46.1 & 74.1 & 104.3 & 30.8 & 447.6 \\
1944 & 29.7 & 10.5 & 9.4 & 17.0 & 179.6 & 104.1 & 15.8 & 21.7 & 5.3 & 80.9 & 287.4 & 240.2 & 1001.6 \\
1945 & 25.2 & 41.2 & 17.2 & 17.0 & 22.2 & 40.7 & 31.5 & 68.2 & 24.8 & 59.1 & 71.7 & 11.7 & 430.5 \\
1946 & 37.7 & 52.3 & 2.7 & 8.3 & 21.0 & 33.9 & 19.9 & 7.0 & 0.9 & 79.9 & 120.0 & 131.9 & 515.3 \\
\hline GEM. & 52.5 & 20.5 & 11.1 & 15.4 & 22.8 & 23.6 & 22.9 & 27.9 & 32.1 & 90.1 & 156.3 & 114.5 & 586.6
\end{tabular}

de kleine buitjes die weinig of geen afstroming geven, mee te tellen. Om de damreservoirs gevuld te krijgen zijn de zware buien nodig, waarvan in een normaal ,goed" regenjaar nooit meer dan 3 of 4 voorkomen. Teneinde met vrij grote zekerheid de vraag te kunnen beantwoorden welk getal dan wel het beste als waarde voor de factor $h$ kan worden bepaald, werden regenvalwaarnemingen van 83 jaren, nl. van $1830 \mathrm{t} / \mathrm{m} 1860$ en van 1895 t/m 1946, nagegaan, waaruit bleek dat i.h.a. in een goed regenjaar de maanden November en December verreweg de regenrijkste maanden zijn, zodat het tijdsverloop dat voor berekening in aanmerking mag komen in principe op 2 maanden werd gesteld. Een periode van 3 maanden zal reeds te veel spreiding 1) opleveren, terwijl 1 maand te gecomprimeerd geacht wordt. $\mathrm{Nu}$ kwamen er voor, op de 83 jaren waarin regenval werd waargenomen:

8 jaren met een regenval van meer dan $450 \mathrm{~mm}$ in 2 maanden

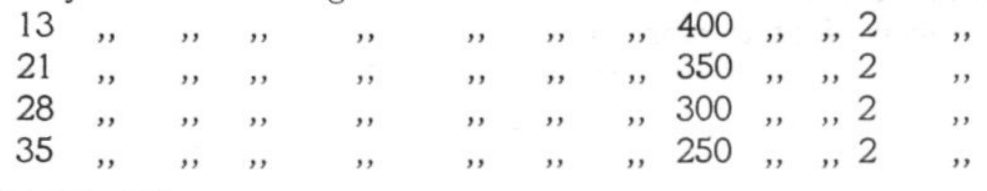

1) Onder spreiding wordt hier verstaan de toenemende kans op kleine buien met weinig of geen afstroming naarmate het tijdvak groter wordt. 
Uit deze gegevens is te concluderen, dat, indien voor de waarde $h 450 \mathrm{~mm}$ genomen zou worden, er een kans van $83 / 8$ is dat de reservoirs van de naar die grondslag berekende dammen voor $100 \%$ gevuld raken, d.i. dus ongeveer 1 maal in de 10 jaren. Wordt $250 \mathrm{~mm}$ genomen, dan is deze kans $83 / 35$, gemiddeld 1 maal per $2 \frac{1}{2}$ jaar, doch dan zal even vaak nog een groot deel naar zee afstromen. Tussen deze twee uitersten moet dus de meest gewenste toestand liggen. Nu ligt het voor de hand om de norm van $350 \mathrm{~mm}$ te nemen, maar omdat ook in een tweemaandelijkse periode nogal wat spreiding kan voorkomen, werd, ter meerdere zekerheid, ook nog de maandelijkse regenval beschouwd met het volgende resultaat:

1 jaar met een regenval van meer dan $450 \mathrm{~mm}$ in 1 maand

\begin{tabular}{|c|c|c|c|c|c|c|c|c|c|}
\hline ,' & ,' & , & ," & ," & ," & ", & 400 & ," & \\
\hline 3 jaren & , , & , & , , & ," & ", & , , & 350 & ", & \\
\hline ", & , , & "' & , , & ", & , , & , & 300 & "' & \\
\hline , & , & , & , , & , & , & ," & 250 & , & , \\
\hline
\end{tabular}

Hieruit blijkt dat slechts 1 maal in de 27 jaren een regenval van meer dan $350 \mathrm{~mm}$ per maand voorkomt, zodat, indien inderdaad $350 \mathrm{~mm}$ als waarde voor de factor $h$ wordt aangenomen, de meeste topregenjaren geborgen kunnen worden en tevens een redelijke kans aanwezig is, dat de damreservoirs van een dergelijk systeem gemiddeld 1 maal per 4 jaar geheel gevuld raken (vgl. de tweemaandelijkse periode $83 / 21$, d.i. rond 4). De factor $h$ dient derhalve op $0.35 \mathrm{~m}$ te worden gesteld.

In de formule $I=\frac{O \times h \times p}{100}$ is dus $p$ de nog onbekende factor, welke door experimenteel onderzoek, zoals omschreven onder $b$ tot klaarheid gebracht zal moeten worden.

Verda m ping s cij fers.

$\mathrm{Nu}$ is er nog een kwestie die bij het hier behandelde onderwerp besproken dient te worden nl. de vraag welk gedeelte van het in de damreservoirs verzamelde water weer door directe verdamping verloren gaat. In tropische streken zijn de verdampingscijfers voor vrije wateroppervlakken vrij hoog en indien het zó zou zijn, dat de verdampingssnelheid b.v. even groot zou blijken te zijn als de infiltratiesnelheid in de damreservoirs dan zou dit dus de kostprijs van het verzamelde water met $100 \%$ doen stijgen . 
Wegens tot nu toe uitblijven van voldoende regenval kon inzake deze belangrijke kwestie nog slechts een onderzoek van korte duur worden ingesteld. In Augustus 1949 was de regenval echter zodanig dat in enkele damreservoirs op Mahuma (Tweede District) een vrij aanzienlijke hoeveelheid water was samengestroomd. Deze mogelijkheid werd onmiddellijk voor een kort onderzoek benut en het resultaat wordt grafisch voorgesteld in fig. 4. In deze grafiek is de verdamping op $8 \mathrm{~mm}$ per dag gesteld (MolengraafF's maximum in Augustus). De opnamen vonden plaats op 23 en 31 Augustus en de conclusie die kan worden getrokken kan nog slechts luiden: $\mathrm{Na}$ een tijdsverloop van 10 dagen is de infiltratiesnelheid nog 5.5 maal zo groot als de verdampingssnelheid. Dit resultaat lijkt dus zeer gunstig,

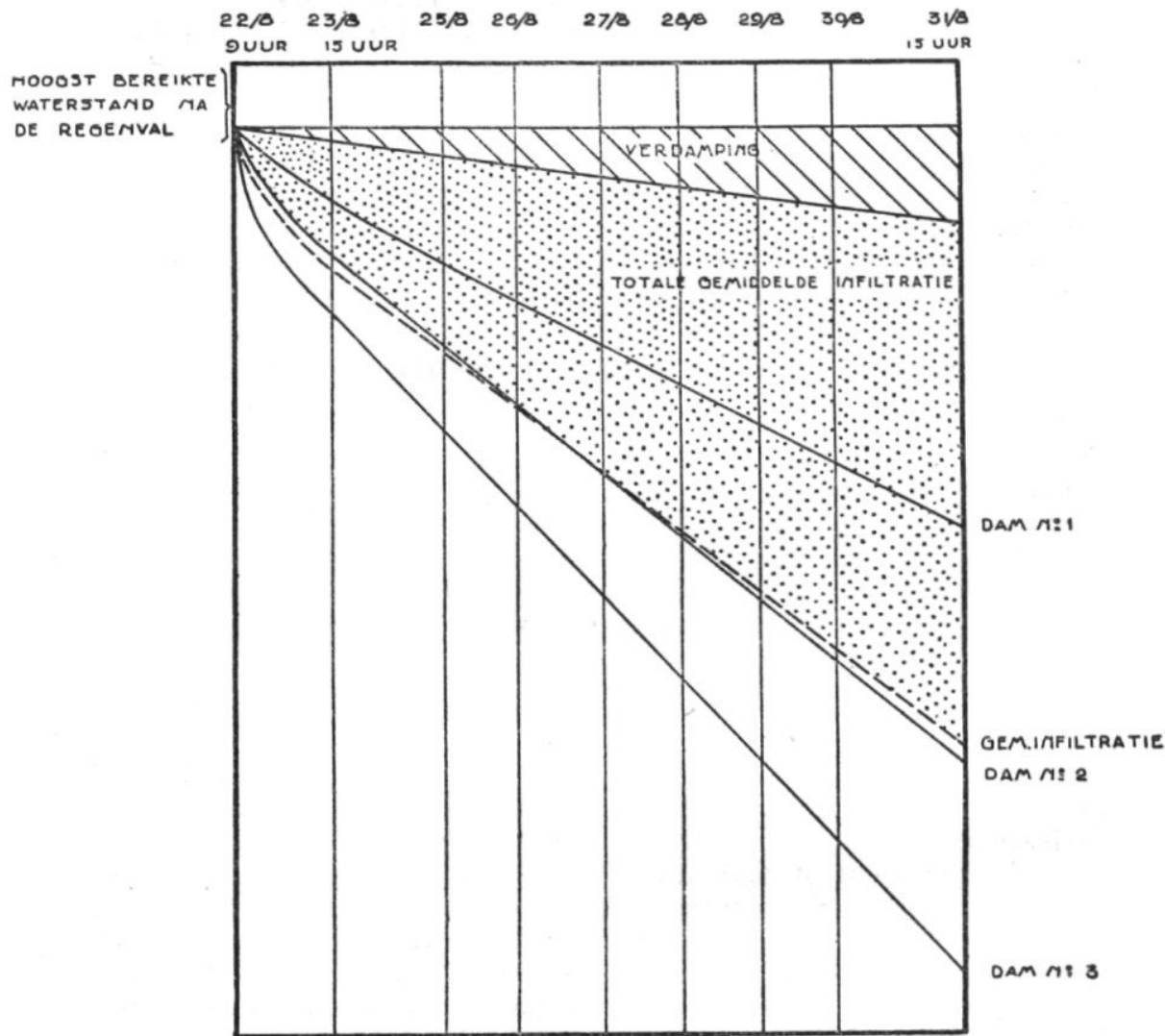

Fig. 4. Grafische voorstelling van de resultaten van een onderzoek naar de infiltratiesnelheid ten opzichte van de verdampingssnelheid in enkele dambassins op Mahuma, Curaçao, van 23-31 Aug. 1949. 
doch om een volledig inzicht te krijgen is een veel langere waarnemingsperiode noodzakelijk. Door het opdrogen van de reservoirs was dit thans niet mogelijk.

In de dissertatie van G. J. H. MolengraAfF (Geologie en geohydrologie van het eiland Curaçao, 1929) wordt op blz. 109 het volgende betreffende verdampingscijfers op Curaçao vermeld:

\begin{tabular}{l|c|cc|cr}
\hline Maand & $\begin{array}{c}\text { Gemiddelde } \\
\text { dagelijkse } \\
\text { verdamping } \\
\text { in mm. }\end{array}$ & \multicolumn{2}{|c|}{ Maximum } & \multicolumn{2}{c}{ Minimum } \\
\hline Jan. (4) & 4.6 & 5.2 & $(1924)$ & $0.0-2.2(1923)$ \\
Feb. (4) & 5.0 & 5.6 & $(1925)$ & 4.2 & $(1923)$ \\
Maart (4) & 5.4 & 6.0 & $(1924)$ & 4.4 & $(1925)$ \\
April (4) & 5.9 & 6.4 & $(1924)$ & 4.2 & $(1925)$ \\
Mei (4) & 6.2 & 6.8 & $(1925)$ & 5.0 & $(1924)$ \\
Juni (4) & 6.4 & 7.6 & $(1926)$ & 5.5 & $(1924)$ \\
Juli (4) & 7.1 & 7.8 & $(1926)$ & 6.0 & $(1924)$ \\
Aug. (4) & 7.4 & 8.0 & $(1926)$ & 6.5 & $(1924)$ \\
Sept. (5) & 7.2 & 7.8 & $(1926)$ & 5.8 & $(1924)$ \\
Oct. (5) & 6.1 & 7.4 & $(1926)$ & $0.0-3.1(1922)$ \\
Nov. (5) & 5.4 & 6.5 & $(1926)$ & $0.0-2.2(1922)$ \\
Dec. (5) & 4.5 & 5.5 & $(1925)$ & $0.0-2.0(1922)$
\end{tabular}

Uit bovenstaande moge gebleken zijn dat aan de oplossing van het grondwaterprobleem op Curaçao intensief gewerkt wordt. Het spreekt vanzelf dat dit probleem nog vele andere aspecten biedt, doch die vallen buiten het bestek van dit artikel.

15 Oct. '49.

\section{SUMMARY}

The water supply may be said to be one of the outstanding problems the Netherlands islands of the Leeward Group have to cope with. A shortage of groundwater results not only in an under supply of drinking water, but also hampers agriculture and horticulture (irrigation) which both require an ample reserve of groundwater.

The Department of Agriculture is now taking measures which may lead to a considerable increase of the supply of groundwater. The first object in view is to prevent the run-off of rainwater to the sea, so that a larger percentage of the rainfall will turn into groundwater. The islands are hilly and the infiltration-capacity of the soil on the slopes is very small, so that, whenever it is raining hard, enormous quantities of water flow towards the sea. This may be prevented by the construction of a damming system (see fig. 1). The startingpoint in the projection of this plan is the principle, that the basin of every dam to 
be constructed must be large enough to contain the quantity of water that may be expected, so that ultimately the capacity of all dambasins together must be about the same as the quantity of water that is flowing off towards the sea in a year with a considerable rainfall. To calculate the required capacity of each dam-basin separately one has to bear in mind that there are three factors, viz:

a. The area that is to provide the water for the dam $(O)$

b. The run-off percentage in case of heavy rainfall $(p)$

c. The number of $\mathrm{mm}$ rainfall that may be taken as a basis for the calculation $(h)$.

The formula for the calculation of the capacity of each dam-basin is consequently

$$
I=\frac{O \times h \times p}{100}
$$

in which formula the factor $O$ is easily found by planimetering from the map. It is not correct to take for factor $h$ the average total rainfall, because showers with a low rain-intensity do not cause run-off. The value of $h$ is calculated by handling the figures for the rainfall during a long period in a certain way. Observations on the island of Curaçao, covering a period of 83 years, make a value of $h$ of $350 \mathrm{~mm}$ acceptable. As regards the value of the very important factor $p$, by means of a simple arrangement an attempt has been made to measure the ratio between the amount of discharged water and the amount of penetrating water in relation to the intensity of the rainfall in various soils, and to get an idea of the intensity of the rainfall with the aid of self recording raingauges. It will be clear that as long as the rainfall-intensity (rain during a given unit of time) does not exceed the infiltration-capacity (rate of infiltration per time-unit) no run-off will take place. (Definition: The run-off percentage is always equal to the positive difference between the rain-intensity and the infiltrationcapacity of the soil).

It is important to know the progress of infiltration-capacity in case of a long period of rain. Some experiments were already made, the result of which is graphically shown in fig. 2. For various reasons, however, the enquiry is not technically perfect and therefore the department looks for an instrument that can work in combination with a selfrecording raingauge. Not only the intensity of the rainfall but also the process of the run-off intensity must be automatically registered.

Fig. 3 gives a theoretical example of what may be attained in that case. In fig. 3 the intensity lines are constructed from the raingauge and run-off meter. The vertical difference between the two lines gives an idea of the progress of the infiltration-capacity of the soil and the vertical difference between the horizontal (zero-line) and the constructed run-off line indicates the run-off.

Still another problem is the question of the rate of evaporation of the water that is collected in the dam-basin with respect to the rate of infiltration in the bottom of the basins. This too must be considered and is now being examined (fig. 4). 